\title{
Antibody Fragments as Tools for Elucidating Structure-Toxicity Relationships and for Diagnostic/Therapeutic Targeting of Neurotoxic Amyloid Oligomers
}

\author{
André L. B. Bitencourt ${ }^{1,+}$, Raquel M. Campos ${ }^{1,+}{ }^{(D}$, Erika N. Cline ${ }^{2}$, William L. Klein ${ }^{2}$ \\ and Adriano Sebollela $1, *$ (D) \\ 1 Department of Biochemistry and Immunology, Ribeirao Preto Medical School, University of São Paulo, \\ Ribeirão Preto, SP 14049-900, Brazil; brandaobqi@hotmail.com (A.L.B.B.); \\ raquelmariacampos@usp.br (R.M.C.) \\ 2 Department of Neurobiology, Northwestern University, Evanston, IL 60208-3520, USA; \\ erika.cline@northwestern.edu (E.N.C.); wklein@northwestern.edu (W.L.K.) \\ * Correspondence: sebollela@fmrp.usp.br; Tel.: +55-16-3315-3109 \\ + These authors contributed equally to this work.
}

Received: 9 September 2020; Accepted: 1 October 2020; Published: 24 November 2020

\begin{abstract}
The accumulation of amyloid protein aggregates in tissues is the basis for the onset of diseases known as amyloidoses. Intriguingly, many amyloidoses impact the central nervous system (CNS) and usually are devastating diseases. It is increasingly apparent that neurotoxic soluble oligomers formed by amyloidogenic proteins are the primary molecular drivers of these diseases, making them lucrative diagnostic and therapeutic targets. One promising diagnostic/therapeutic strategy has been the development of antibody fragments against amyloid oligomers. Antibody fragments, such as fragment antigen-binding (Fab), scFv (single chain variable fragments), and VHH (heavy chain variable domain or single-domain antibodies) are an alternative to full-length IgGs as diagnostics and therapeutics for a variety of diseases, mainly because of their increased tissue penetration (lower MW compared to IgG), decreased inflammatory potential (lack of Fc domain), and facile production (low structural complexity). Furthermore, through the use of in vitro-based ligand selection, it has been possible to identify antibody fragments presenting marked conformational selectivity. In this review, we summarize significant reports on antibody fragments selective for oligomers associated with prevalent CNS amyloidoses. We discuss promising results obtained using antibody fragments as both diagnostic and therapeutic agents against these diseases. In addition, the use of antibody fragments, particularly scFv and $\mathrm{VHH}$, in the isolation of unique oligomeric assemblies is discussed as a strategy to unravel conformational moieties responsible for neurotoxicity. We envision that advances in this field may lead to the development of novel oligomer-selective antibody fragments with superior selectivity and, hopefully, good clinical outcomes.
\end{abstract}

Keywords: antibody fragments; single chain; amyloid; oligomer; neurotoxicity; NUsc1

\section{Toxic Protein Oligomers in Central Nervous System Diseases}

In living systems, proteins must assume and maintain a three-dimensional conformation, which dictates their biological functions. Under certain conditions, however, monomeric protein units may self-associate to form oligomeric structures that display both loss of biological, and gain of toxic, function [1]. Ultimately, these oligomers have the potential to aggregate into insoluble amyloid fibrils, highly stable non-branched insoluble structures rich in $\beta$-sheet content [2-4]. Although this 
property is inherent to all proteins [5-7], a number of amyloidogenic proteins accumulate in tissues, causing diseases known as amyloidoses, which can be systemic but commonly impact the central nervous system (CNS) [1,8-11].

It is now evident that soluble oligomers are the most toxic form of amyloidogenic proteins, more so than their monomeric or fibrillar forms, disrupting, e.g., synaptic function, membrane permeability, calcium homeostasis, gene transcription, mitochondrial activity, autophagy, and/or endosomal transport in an array of disease models [12-15]. The first reports on the brain accumulation of toxic soluble oligomers were in Alzheimer's disease (AD); the associated oligomers mainly composed of the $4.5 \mathrm{kDa}$ amyloid $\beta(\mathrm{A} \beta)$ peptide [16-18]. Since then, toxic soluble oligomers of other proteins have been implicated in the onset and progression of several debilitating CNS diseases, e.g., tau, $\alpha$-synuclein, the prion protein $\left(\mathrm{PrP}^{\mathrm{c}}\right)$, and huntingtin protein (htt) in Alzheimer's, Parkinson's, prion, and Huntington's diseases, respectively [19-24]. In fact, many of these protein oligomers are found together in multiple diseases $[25,26]$.

Amyloidogenic oligomers have been frequently implicated as promising diagnostic and therapeutic targets for CNS amyloidoses [12,14,27-33]. Despite their disease relevance, the structural hallmarks of such soluble oligomers remain elusive due to their metastability and heterogeneity, hampering our ability to target them therapeutically and diagnostically [12,34-36]. One promising strategy in the structural analysis of amyloidogenic oligomers is the utilization of antibody fragments, which can achieve high conformational selectivity, enabling the isolation and stabilization of different oligomeric species. Furthermore, the structural properties of the antibody fragments themselves make them promising diagnostic/therapeutic tools. In this review, we discuss their application as tools for structural research and diagnostic/therapeutic targeting of oligomers acting in brain amyloidoses.

\section{Antibody Fragments}

Monoclonal antibodies (mAbs) are currently the largest, and most rapidly growing, class of biopharmaceuticals on the market to treat a variety of diseases [37,38]. However, only four mAbs have been approved to treat a neurodegenerative disease (multiple sclerosis), and these antibodies are thought to work primarily in the periphery [37]. There are a number of challenges in utilizing monoclonal antibodies for the diagnosis or treatment of brain diseases. For one, their large molecular mass hinders their ability to cross the blood-brain barrier [38,39]. Moreover, the crystallizable fraction (Fc) of mAbs can mediate deleterious inflammatory responses resulting in, e.g., meningoencephalitis, vasogenic edema, cerebral microhemorragies, and even death [40-47]. Regarding diagnostics, poor contrast of mAbs in imaging applications due to a long serum half-life has been reported as a drawback [48].

During the past 20 years, antibody fragments have been developed as an alternative to full-length IgGs for the diagnosis and treatment of a variety of diseases, including brain disorders $[13,38,39,47,49-52]$. These molecules are simple protein motifs of large diversity that include the IgG antigen-binding domain(s) but lack the inflammatory $F_{c}$ domain, retaining the total (fragment antigen-binding: Fab and single-chain variable fragment: $\mathrm{scFv}$ ) or partial (VH) antigen specificity of intact IgGs [38,39,52].

Compared to full-length IgGs, antibody fragments have advantages and disadvantages as therapeutics. An important advantage is their smaller size $(12-50 \mathrm{kDa})$, thought to potentiate the blood-brain barrier crossing and tissue penetration and enable access to challenging, cryptic epitopes $[38,39,52]$. Furthermore, their fast blood clearance makes them ideal imaging agents [39]. On the other hand, their smaller size leads to a shorter half-life in vivo, in part due to rapid kidney clearance, which limits the chance of target engagement without the addition of half-life extension moieties (e.g., PEG and albumin-binding fragments) $[38,44]$. Another advantage of antibody fragments, is their lack of the inflammatory Fc domain (see discussion above). On the other hand, it is noteworthy that the lack of Fc-dependent activation of immune cells may reduce the efficiency of an immunotherapy when a robust inflammatory response is required [53,54], as in cancer immunotherapy, which requires $\mathrm{T}$ cell recruiting [55]. 
Another advantage of antibody fragments, is their excellent manufacturability and low cost of production $[38,39]$. They can be efficiently selected from in vitro display libraries (phage or yeast) and cloned and expressed in heterologous expression systems (e.g., bacteria); this facilitates the production of large quantities in an easy and affordable way. Importantly, the in vitro approach eliminates animal immunization, which may be key when the conformation of the immunogen plays a role in antibody specificity $[46,56]$. Finally, engineered antibody fragments yielding multimers (diabodies, triabodies, and tetrabodies) have been shown to present higher avidity and lower blood clearance than their monomeric counterparts without compromising tissue penetration abilities [38,48,54].

The main types of antibody fragments under development are $\mathrm{Fab}, \mathrm{scFv}$ (single chain variable fragments), and heavy chain variable domain $\mathrm{VH} / \mathrm{VHH}$ (single-domain antibodies) fragments $[38,39,49,52,57]$. The potential of isolated light chain variable domain (VL) chains has not been significantly investigated due to their low stability [56]. An overview of the structures of these molecules is presented in Figure 1. The first artificial antibody fragments reported in the literature were initially obtained by removing the Fc domain through proteolysis [44]. Later advances have enabled the further reduction of antibody structure to $\mathrm{scFv}$ and $\mathrm{VH} / \mathrm{VHH}$ (also called minibodies or nanobodies) $[38,39,52-54,57]$. These fragment types are described in more detail below.

A
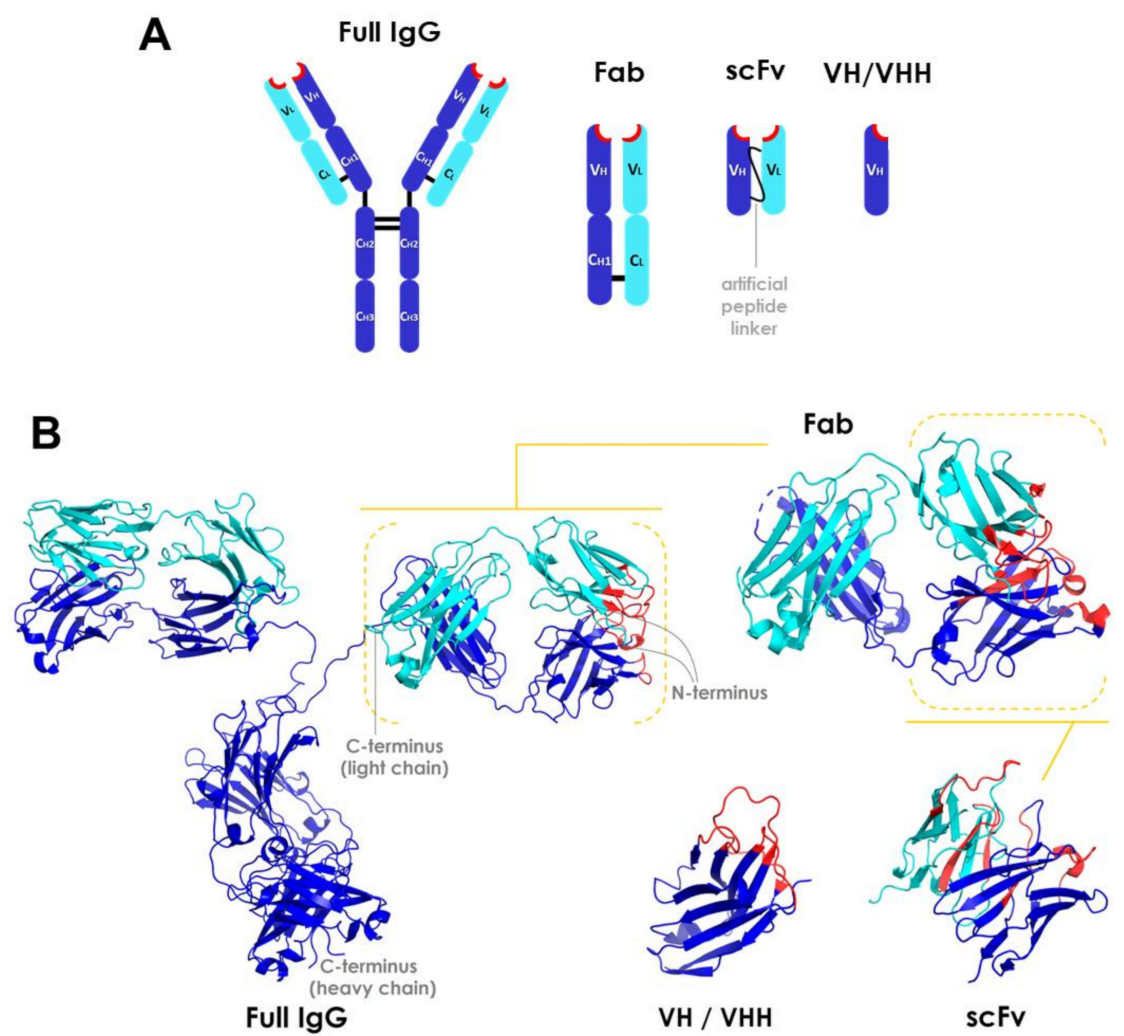

Figure 1. Overview of the structure of antibody fragments. (A) General schematic of domain framework and (B) ribbon diagrams of full-length IgG and fragment molecules. Structures were obtained from the Protein Data Bank (http://www.rcsb.org/pdb/). CH, CL, VH, and VL stand for constant heavy, constant light, variable heavy, and variable light domains, respectively. Heavy or light chains are depicted in dark blue or cyan, respectively. Complementarity-determining region (CDR) segments are highlighted in red. PDB codes: 1IGT (full length IgG), 5VH3 (Fab), 4NKO (scFv), and 3R0M (VHH) [58]. Fab: fragment antigen-binding; scFv: single chain variable fragments; VH/VHH: heavy chain variable domain fragment. 
Fab fragments are independent structural units of $\sim 50 \mathrm{kDa}$ containing two antigen-binding sites, with the heavy chain variable domain $(\mathrm{VH})$ linked to the heavy constant domain 1 (CH1) and the light chain variable domain (VL) linked to the light constant domain (CL) [44]. These domains interact through a large interface between the chains $(\mathrm{VH} / \mathrm{VL}$ and $\mathrm{CH} 1 / \mathrm{CL})$ and a small one between the variable and the constant domains $(\mathrm{VH} / \mathrm{CH} 1$ and $\mathrm{VL} / \mathrm{CL})$ of each chain [59]. The packing between the variable domains creates the antigen binding site [56]. The $\mathrm{CH} 1$ and $\mathrm{CL}$ domains are also covalently connected by a disulfide bond between Cys residues at their carboxyl terminal region [60,61]. Each Ig domain presents two layers of $\beta$-sheet structures, with three to five $\beta$-sheets per layer. The variable Ig domains (cyan; Figure 1B) are slightly longer than the constant domains (dark blue; Figure 1B), as they contain two more $\beta$-sheets per layer. The $\beta$-sheets are connected through loops, and the $\beta$-sheet layers of constant domains are attached through a disulfide bond. All amino terminal variable domain loops pack together in a $\beta$-sheet motif arranged as an antiparallel barrel-like structure, forming the complete complementarity-determining region (CDR), which is ultimately responsible for the antibody specificity (highlighted in red in Figure 1B) $[44,59]$. Each Ig domain contains three amino terminal loops encoding different CDR segments. Since the sequence variation associated with the specificity of immunoglobulins is found in CDRs, these regions are also referred to as hypervariable regions [59]. The hypervariable regions assemble into the antigen binding site and interact directly with the epitope. The framework regions, those comprising the variable domain sequences besides CDRs, fold into $\beta$-sheet motif structures and provide the scaffold for antibody-antigen interactions [62].

Single-chain variable fragments (scFvs), the smallest antibody fragments containing a complete antigen binding site, are recombinant molecules of $\sim 30 \mathrm{kDa}$ in which the variable domains of both $\mathrm{VL}$ and $\mathrm{VH}$ chains are engineered into a single polypeptide chain connected by a flexible peptide linker and/or a disulfide bond [20,43,45,46]. Their hypervariable segments (amino terminal loops) are approximately 10 amino acid residues long and, as in full length IgGs, form the antigen binding site [59]. The length and amino acid composition of the linker are crucial in maintaining the correct fold of these proteins [54]. The linker is typically about $3.5 \mathrm{~nm}$ in length and must contain small, hydrophilic residues (typically Gly and Ser) for enhanced solubility and flexibility [44,54].

$\mathrm{VH} / \mathrm{VHH}$ fragments ( 15-20 kDa) are N-terminal Ig domains derived only from the heavy chain, thus retaining antigen binding specificity within a single polypeptide domain $[53,59,63]$. Similar to $\mathrm{VH}$ fragments (Figure 1), VHHs (high affinity variable domains naturally found in camelids) contain three CDRs forming the antigen binding site [59,62]. Human VH domains and camelid VHH framework regions show a high sequence homology [61]. VHH fragments are naturally occurring $[38,39,49,52]$ and especially stable.

\section{Antibody Fragments Assisting the Study, and Diagnostic/Therapeutic Targeting, of Neurotoxic Amyloid Oligomers in CNS Amyloidoses}

In the last two decades, several studies using antibody fragments to study the role of protein oligomers in CNS amyloidoses have been published (Table 1). Considering the discussion in the first two sections above, a major motivation for the use of antibody fragments as research and diagnostic/therapeutic tools for this disease class is the augmented chance of obtaining high affinity, conformation-sensitive antibodies over the typical animal immunization approach. Antibody fragments that display high selectivity for toxic oligomeric conformations are likely to be capable of neutralizing these neurotoxic aggregates without interfering with the physiological function of their monomeric counterparts, therefore presenting as preferred candidates for immunotherapies to treat amyloidogenic diseases. In the following sections, we review studies describing conformational antibody fragments capable of recognizing soluble oligomeric species formed by distinct proteins linked to prevalent CNS amyloidosis that currently lack a cure. We also highlight reports that, in our view, should provide guidance for the development of improved antibody fragments targeting neurotoxic oligomers. 
Table 1. Conformation-sensitive antibody fragments directed to oligomeric species of proteins implicated in central nervous system (CNS) amyloidoses.

\begin{tabular}{|c|c|c|c|c|c|}
\hline \multirow{2}{*}{ Antibody } & \multirow{2}{*}{ Fragment Type } & \multirow{2}{*}{ CNS Amyloidosis } & \multicolumn{2}{|c|}{ Target } & \multirow{2}{*}{ Ref. } \\
\hline & & & High Affinity * & Low Affinity & \\
\hline NUsc1 & $\mathrm{scFv}$ & $\mathrm{AD}$ & $\begin{array}{c}\text { A } \beta 42 \text { Oligomers } \\
(>50 \mathrm{kDa})^{\mathbb{I}}\end{array}$ & not reported & {$[64,65]$} \\
\hline MO6 & $\mathrm{scFv}$ & $\mathrm{AD}$ & $\begin{array}{l}\text { A } \beta 42 \text { Oligomers and } \\
\text { Immature fibrils } \\
(18-37 \mathrm{kDa} \#)\end{array}$ & not reported & [66] \\
\hline AS & $\mathrm{scFv}$ & $\mathrm{AD}$ & $\begin{array}{c}\mathrm{A} \beta 42 \text { Oligomers and } \\
\text { Immature } \\
\text { Protofibrils } \\
(25-55 \mathrm{kDa} \#)\end{array}$ & not reported & {$[67]$} \\
\hline HT6 & $\mathrm{scFv}$ & $\mathrm{AD}$ & $\begin{array}{c}\text { A } \beta 42 \text { Oligomers } \\
\left(18-45 \mathrm{kDa}^{\#}\right)\end{array}$ & not reported & {$[68]$} \\
\hline $11 \mathrm{~A} 5$ & $\mathrm{scFv}$ & $\mathrm{AD}$ & $\begin{array}{l}\text { A } \beta 42 \text { Oligomers } \\
\left(34 \mathrm{kDa}^{\#}\right)\end{array}$ & not reported & [69] \\
\hline A4 & $\mathrm{scFv}$ & $\mathrm{AD}$ & $\mathrm{A} \beta 42$ Oligomers & $\begin{array}{l}\mathrm{A} \beta 42 \text { Monomers } \\
\text { and Fibrils }\end{array}$ & {$[70]$} \\
\hline E1 & $\mathrm{scFv}$ & $\mathrm{AD}$ & $\mathrm{A} \beta 42$ Oligomers & not reported & {$[71]$} \\
\hline scFv59 & $\mathrm{scFv}$ & $\mathrm{AD}$ & $\begin{array}{c}\mathrm{A} \beta 42 \text { Oligomers and } \\
\text { Plaques }\end{array}$ & not reported & {$[72]$} \\
\hline scFv235 & $\mathrm{scFv}$ & $\mathrm{AD}$ & $\begin{array}{l}\text { phosphoTau } \\
\text { Oligomers } \\
(50-70 \mathrm{kDa}) \#\end{array}$ & Tau monomers & [73] \\
\hline $\begin{array}{l}\text { F9T, D11C, } \\
\text { H2A }\end{array}$ & $\mathrm{scFv}$ & $\mathrm{AD}$ & $\begin{array}{l}\text { Tau Oligomers } \\
\text { (Trimers) } \mathbb{I}\end{array}$ & not reported & {$[74]$} \\
\hline RN2N & $\mathrm{scFv}$ & $\mathrm{AD}$ & Tau Oligomers & not reported & [75] \\
\hline D5 & $\mathrm{scFv}$ & PD & $\begin{array}{l}\alpha \text {-Synuclein } \\
\text { Oligomers }\end{array}$ & not reported & {$[76]$} \\
\hline $10 \mathrm{H}$ & $\mathrm{scFv}$ & PD & $\begin{array}{l}\alpha \text {-Synuclein } \\
\text { Oligomers } \\
\text { (Trimers and } \\
\text { Hexamers) } \mathbb{I}\end{array}$ & $\begin{array}{l}\alpha \text {-Synuclein } \\
\text { Monomers }\end{array}$ & {$[77]$} \\
\hline $\begin{array}{c}\text { VH14, } \\
\text { NbSyn87 }\end{array}$ & $\mathrm{VH}$ & PD & $\begin{array}{l}\alpha \text {-Synuclein } \\
\text { Oligomers }\end{array}$ & not reported & {$[78]$} \\
\hline D5-ароB & $\mathrm{scFv}$ & PD & $\begin{array}{c}\alpha \text {-Synuclein } \\
\text { Oligomers } \\
(28-80 \mathrm{kDa})^{\#}\end{array}$ & not reported & [79] \\
\hline W20 & $\mathrm{scFv}$ & Various diseases & $\begin{array}{c}\text { Oligomers of } \mathrm{A} \beta 40 \\
\text { and } \mathrm{A} \beta 42, \operatorname{PrPC} \\
\alpha \text {-Syn, amylin, } \\
\text { insulin, lysozyme }\end{array}$ & not reported & {$[80]$} \\
\hline
\end{tabular}

${ }^{*} \mathrm{MW} /$ size of targeted oligomers is presented when available. It is also indicated whether MW/size have been determined under non-denaturing ${ }^{\mathbb{I I}}$ or denaturing \# conditions. AD: Alzheimer's Disease; PD: Parkinson's Disease; $\operatorname{PrP}^{\mathrm{C}}$ : cellular prion protein.

\subsection{Alzheimer's Disease}

\subsubsection{Amyloid $\beta$}

The increasing collection of antibody fragments against toxic aggregates associated with Alzheimer's Disease (AD) has enabled the elucidation of important information related to the biochemical nature of these toxic aggregates and their contribution to AD pathogenesis. As discussed above, a major challenge for all amyloidogenic proteins, but perhaps especially for the AD toxins $A \beta$ oligomers (A $\beta O s)$, has been to identify the most toxic aggregated species. This difficulty in characterization is due to the heterogeneous distribution of metastable species (including non-toxic or 
differentially toxic species) formed during the aggregation process [81]. Although robust evidence suggests that soluble $\mathrm{A} \beta \mathrm{O}$ s and protofibrils play a prominent role in $\mathrm{AD}$ progression $[12,82]$, the precise structural features of these soluble aggregates that contribute to $\mathrm{AD}$ pathogenesis remain elusive $[1,12,81]$. However, recent advances in this area have been made possible with the use of conformation-selective fragment antibodies $[64-72,82,83]$. One of those is the scFv antibody NUsc1, selected from a phage-display library by our group $[64,65]$. NUsc1 presents a marked selectivity for soluble $\mathrm{A} \beta \mathrm{O}$ s compared to monomers or fibrils (Figure $2 \mathrm{~A}$ ) and, importantly, provides neuroprotection against $\mathrm{A} \beta \mathrm{O}$ toxicity in cell cultures, blocking $\mathrm{A} \beta \mathrm{O}$ binding and reducing $\mathrm{A} \beta \mathrm{O}$-induced oxidative stress and Tau hyperphosphorylation $[64,65]$. NUsc1 is of particular interest since it recognizes a unique conformational epitope displayed on oligomers of $A \beta$ but not those formed by other proteins (such as Tau or Lysozyme); other anti-A $\beta \mathrm{O}$ scFvs have been shown to recognize a common epitope present on oligomers formed by different proteins [73,81,84]. Moreover, NUsc1 exhibits a marked oligomer size-dependent selectivity, preferentially targeting neurotoxic $\mathrm{A} \beta \mathrm{O}$ species larger than $50 \mathrm{kDa}$, as analyzed under non-denaturing conditions by size-exclusion chromatography (Figure 2B).
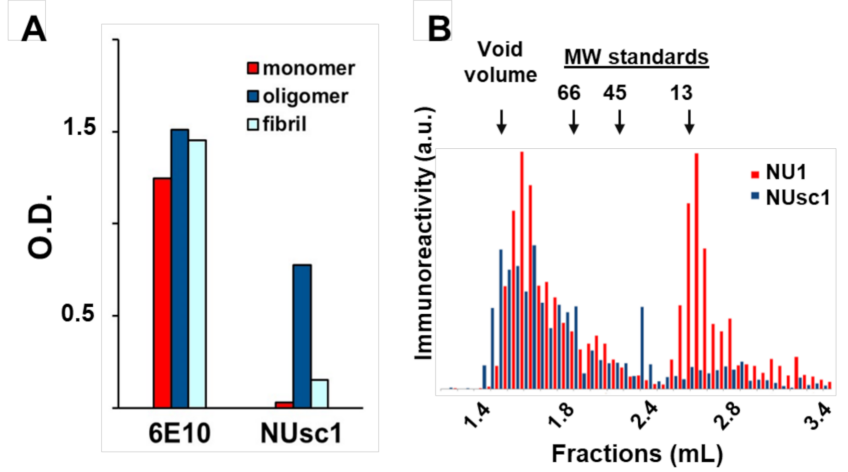

Figure 2. The scFv antibody NUsc1 is highly selective to high molecular weight $A \beta$ oligomers (A $\beta O)$. (A) NUsc1 shows high selectivity for $A \beta$ oligomers over monomers and fibrils as determined via ELISA. The anti-pan A $\beta$ IgG 6E10 is shown for comparison. Adapted with permission from (Velasco et al., ACS Chem. Neurosci. 2012 [64]). Copyright (2020) American Chemical Society. (B) Within a synthetic $\mathrm{A} \beta \mathrm{O}$ population, NUsc1 selectively targets a high molecular weight subset, showing little binding to a lower molecular weight subset that is readily bound by the anti-A $\beta \mathrm{O}$ IgG NU1. Reactivity of both antibodies to $\mathrm{A} \beta \mathrm{O}$ fractions separated by size-exclusion chromatography under non-denaturing conditions was determined by dot immunoblotting. Reprinted with permission from (Sebollela et al., Journal of Neurochem. 2017 [65]). Copyright (2020) John Wiley and Sons.

Other anti-A $\beta \mathrm{O}$ scFvs have been reported that are promising tools for the study of $\mathrm{A} \beta \mathrm{O}$ structure-toxicity relationships as well as their diagnostic and therapeutic targeting. The scFv MO6 was found to target $\mathrm{A} \beta \mathrm{O}$ species $(18-37 \mathrm{kDa})$ that are on-pathway to fibril formation and toxic to SH-SY5Y cells [66]. Important to its diagnostic/therapeutic potential, MO6 was demonstrated to cross the blood-brain barrier (BBB) in an in vitro BBB model with a delivery efficiency of $66 \% 60 \mathrm{~min}$ post-administration. Another study reported the $\mathrm{scFv}$ b4.4, which recognized an epitope in the central region of $\mathrm{A} \beta 42$ (comprising residues $\mathrm{H}^{13}, \mathrm{~K}^{16} \mathrm{~V}^{18}, \mathrm{~F}^{19}$ ) and was able to neutralize the toxicity of either $\mathrm{A} \beta \mathrm{Os}$ or fibrillar A $\beta$ to SH-SY5Y cells [83]. The scFv AS was found to recognize cytotoxic medium-sized A $\beta O$ species (25-55 kDa) and protofibrils [67]. While scFvs are commonly identified via phage display, AS was identified from a library constructed from the immune repertoire of AD patients. The scFv HT6 also was found to bind efficiently to an $\mathrm{N}$-terminal epitope present in cytotoxic medium-sized $\mathrm{A} \beta \mathrm{Os}$ (mainly $18-45 \mathrm{kDa}$ ) in vitro [68]. Significantly, the anti-A $\beta \mathrm{O}$ scFv $11 \mathrm{~A} 5$, selected by phage display and found to target a $34 \mathrm{kDa}$ assembly, has been reported to ameliorate cognitive decline in rats induced by injection of $A \beta O s$ [69]. It is important to consider that in all of these studies, $A \beta O$ size has been evaluated by denaturing SDS-PAGE/Western immunoblotting, and therefore may not accurately reflect 
the $\mathrm{A} \beta \mathrm{O}$ size in the physiological milieu. Additionally, an interesting approach has been developed wherein atomic force microscopy is utilized to biopan for conformation-selective antibodies by phage display. Following this approach, two scFvs were identified, named A4 and E1, that targeted distinct oligomeric species presenting either high [70] or low [71] cytotoxicity potentials. Further studies with these conformer-selective scFvs, and others like them, promise to shed additional light on the $\mathrm{A} \beta \mathrm{O}$ structural properties contributing to $\mathrm{AD}$ pathogenesis.

The scFvs highlighted above were all identified by their unique selectivities from antibody libraries. One promising strategy for the rational engineering of scFvs with even further improved selectivity for oligomeric species of interest, is complementarity-determining region (CDR) mapping (i.e., determination of the complementarity-determining region (CDR) amino acid sequences, the regions responsible for antibody specificity) of existing scFvs. So far, CDR mapping has only been reported for non-conformational anti-A $\beta$ scFvs. In one of these reports, Tiller and colleagues (2017) used a series of mutations in the CDR sequences of scFvs to identify the contribution of arginine residues to the affinity and selectivity for $A \beta$ monomers [85]. Other recent studies have contributed to the identification and importance of particular amino acids within CDRs, e.g., tyrosine, glycine, serine, and especially arginine, in the binding to different $A \beta$ aggregated species [86,87]. If similar studies are conducted with anti-A $\beta \mathrm{O}$ scFvs in the future, comparison to these data obtained with non-conformational anti-A $\beta$ scFvs may indicate the key interactions underlying conformational preference for oligomeric over monomeric and fibrillar species. From a therapeutic perspective, the ectopic expression of neurotoxic-selective fragment antibodies by using brain-optimized viral vectors is emerging as an exciting path to be exploited. For instance, recent data in AD-mouse models indicate a cognitive benefit provided by the brain expression of the scFv NUsc1, which was discussed above (unpublished data [88]).

\subsubsection{Tau}

Another AD-relevant amyloidogenic protein is the microtubule-associated protein Tau. Upon abnormal hyperphosphorylation or co-factor binding, this protein forms oligomers and larger aggregates that contribute to neuronal dysfunction and death in $\mathrm{AD}$ and other tauopathies (reviewed in $[89,90])$. Since Tau oligomers have been linked to neurodegeneration, structural studies aimed to unravel the conformation of soluble Tau aggregates have been the focus of recent investigations [91]. As with A $\beta O s$, antibody fragments are emerging as promising tools for these studies $[74,75,92]$. For instance, Tian et al. (2015) reported the selection of three conformation-selective anti-Tau scFvs (F9T, D11C, H2A) capable of binding trimeric but not monomeric or fibrillar Tau [74]. These scFvs distinguished $\mathrm{AD}$ from cognitively normal post-mortem human brains and are capable of detecting oligomeric Tau at earlier ages, compared to typical ages in which neurofibrillary tangles can be detected. In terms of therapy, these oligomer-selective $\mathrm{scFv}$ antibodies represent an advantage over non-conformational antibodies as they do not block the physiological functions carried out by monomeric Tau.

\subsection{Parkinson's Disease}

Parkinson's disease (PD) is a neurodegenerative disorder associated with the abnormal aggregation of the neuronal membrane protein alpha synuclein ( $\alpha$-syn) (reviewed in Shulz-Schaeffer [93]). It has been shown that, besides the formation of insoluble aggregates that deposit inside neurons as inclusion bodies, termed Lewy bodies, $\alpha$-syn also forms neurotoxic soluble oligomers/protofibrils [94,95]. As with $\mathrm{A} \beta$ and Tau, antibody fragments are beginning to emerge in the literature with selectivity for oligomeric over monomeric or fibrillar forms of $\alpha$-syn. Emadi and colleagues have identified two scFv antibodies of particular use in elucidating $\alpha$-syn oligomer structure-function relationships. The scFv D5 was found to be selective for oligomers more abundant in initial stages of $\alpha$-syn aggregation and to block further aggregation of these oligomers and their toxicity in SH-SY5Y cells [76]. D5 was also seen to interact with oligomers formed by the Huntington's disease-associated protein htt51Q [96], in line 
with the notion that many antibodies raised against amyloid oligomers cross-react with structurally similar oligomers formed by non-related proteins [97]. In contrast, $10 \mathrm{H}$, an $\mathrm{scFv}$ that targets oligomers more abundant in later stages of $\alpha$-syn aggregation, appears to be selective for oligomers of $\alpha$-syn [77]. Both scFvs D5 and $10 \mathrm{H}$ provided neuroprotection in an $\alpha$-syn overexpressing transgenic mouse model when fused to penetratin (a cell-penetrating peptide), raising a potential immunotherapeutic benefit of these scFvs in PD [98]. Although in principle antibodies targeting pan-amyloid aggregates such as scFv D5 may represent a promising therapeutic strategy, it is also important to consider that cross-reactivity may be harmful in some cases. For instance, Kvam et al. (2009) showed that the anti-fibrillar $\alpha$-syn scFv-6E, which also binds mutant huntingtin and ataxin-3, increased the aggregation of these polyglutamine-rich proteins in striatal cells, aggravating intracellular dysfunction and cell death [99].

Although few antibody fragments selective for oligomeric $\alpha$-syn conformations have been reported in the literature, studies utilizing antibody fragments selective for linear $\alpha$-syn sequences (i.e., non-conformational antibodies) have increased our understanding of $\alpha$-syn aggregation and toxicity. Zhou et al. (2004) reported the scFv antibody D10, which presented nanomolar affinity for $\alpha$-syn monomers and inhibited aggregation to oligomeric and protofibrillar forms. The authors localized the D10 epitope within the C-terminus of $\alpha$-syn, suggesting that perturbation in this region interferes with the aggregation process. In the same study, it was also shown that co-expression of D10 in HEK293 cells engineered to overexpresses $\alpha$-syn reduced the formation of high-molecular weight $\alpha$-syn aggregates, thus suggesting a positive action of D10 as an intrabody [100] (i.e., a fragment antibody engineered to accumulate within its producing cell). The VHH single domain antibodies NbSyn2 and NbSyn87 have been used to identify the role of different C-terminal regions of $\alpha$-syn in fibril formation [101-103]. NbSyn2, which recognizes an epitope between residues 136-140, did not affect fibril formation $[78,102,103]$. In contrast, NbSyn87, which recognizes an epitope comprised by residues 118-128, induced conformational changes on both secondary and tertiary structures of $\alpha$-syn, consequentially reducing the half-time of fibril formation $[78,101]$.

scFvs targeting the $\alpha$-syn nonamyloid component (NAC) have also shown therapeutic promise in pre-clinical studies. The NAC presents a high tendency to adopt $\beta$-pleated sheet structures and is known to play a key role in the aggregation and toxicity of $\alpha$-syn in vitro and in vivo [104]. In 2008, Lynch and colleagues showed a novel NAC-selective scFv named NAC32 capable of reducing the aggregation and neurotoxicity of $\alpha$-syn aggregates [105]. Other single domain antibodies targeting the NAC, NAC1 and VH14, acted similarly to NAC32 in preventing a-syn aggregation [106].

Although considerable advances towards the understanding of $\alpha$-syn aggregation and toxicity have been attained by the use of fragment antibodies, few reports have been published so far evaluating the consequences of the in vivo expression/administration of these antibody fragments. Although few, these reports do demonstrate therapeutic promise. In one of these studies, the single-domain antibodies VH14 and NbSyn87 were expressed in fusion with the proteasome-targeting PEST motif, resulting in increased cytoplasmic solubility and enhanced degradation of $\alpha$-syn in neuronal cell lines [78]. In another interesting piece of work, Spencer et al. (2014) induced the expression of a scFv directed to $\alpha$-syn oligomers in fusion with the low-density lipoprotein receptor-binding domain from apolipoprotein B (LDL ApoB) in vivo [79]. This construction increased the penetration of the $\mathrm{scFv}$ into the brain via the endosomal sorting complex required for transport (ESCRT) pathway, consequently leading to lysosomal degradation of $\alpha$-syn aggregates [79]. These exciting reports suggest the feasibility of in vivo expression of engineered anti-oligomeric scFvs as a therapeutic alternative for PD.

\subsection{Huntington's Disease}

Huntingtin (HTT) is a ubiquitously expressed large protein (3144 amino acids) involved in the pathogenesis of Huntington's disease (HD) [107]. Although the diverse physiological roles of HTT are not yet fully understood, it is well known that its aggregation and neurotoxicity are 
dependent on the presence of an aberrant polyglutamine (polyQ) stretch encoded in exon 1 of the htt gene (corresponding to the N-terminus in the protein) [108-110]. In mutant-disease-associated HTT, this polyQ stretch is longer than in wild type HTT, reaching 40 or more glutamine residues (as opposed to normally 20 on average) [110]. Interestingly, this increment is enough to impact the stability of the whole molecule, driving its aggregation into both soluble oligomers and insoluble aggregates [111].

Since HTT aggregates are exclusively intraneuronal, intrabodies have been the antibody fragment type preferentially applied to their structure-function study and their therapeutic targeting. One of the first scFv-type intrabodies directed to huntingtin was reported by Lecerf et al. (2001). Named C4, this scFv binds to residues 1-17 of HTT, a sequence N-terminal to the polyQ repeat in HTT exon 1 , stabilizing an alpha helix-rich oligomeric complex and preventing amyloid formation [112,113]. When co-expressed with HTT exon 1 in non-neuronal cells, C4 was capable of reducing the amount of HTT aggregates and redirecting the subcellular localization of HTT exon 1. Moreover, C4 efficiently reduced cell death in malonate-treated brain slice cultures expressing mutant HTT [114]. Additionally of importance, expression of C4 in the HD disease mouse model B6.HDR6/1, via AAV2/1 vector, led to delayed HTT aggregation in both early and late disease stages [115]. The authors also generated $\mathrm{scFv}-\mathrm{C} 4$ in fusion with the PEST domain to increase proteasomal degradation of the antigen-antibody complex [115].

A piece of pioneering work by Khoshnan et al. (2002) reported three scFvs (MW1, MW2, and MW7) produced by cloning the antigen-binding domains of monoclonal IgGs targeting either polyQ or an adjacent domain in HTT exon 1 rich in proline residues (named PRD) into scFv scaffolds [116]. The scFv MW7, selective for PRD, inhibited cell death induced by mutant HTT in co-transfected HEK293 cells [116]. Surprisingly MW1 and MW2, both selective for polyQ, accelerated aggregation and cell death in the same culture model. Possible explanations for this unexpected result are that MW1 and MW2 either stabilized a toxic aggregated conformation of HTT or interfered with the binding of HTT to other molecules mediating HTT toxicity [116]. These findings highlight the complexity and importance of identifying fragment antibodies that indeed target toxic oligomeric species, which are expected to show promise as therapeutics and/or diagnostics.

In another piece of work, multiple intrabodies targeting HTT PRD domains (scFv MW7; VL Happ1; VL Happ3) or the HTT N-terminus (VL 12.3) were used to investigate the role of these domains in HTT aggregation and toxicity [117]. VL 12.3 had been previously shown to reduce toxicity in a neuronal culture model of HD [118]. All of these intrabodies reduced mutant HTT exon 1 aggregation and toxicity in both cell culture and brain slice models of HD, although the mechanisms of protection were different. While the N-terminus-targeting intrabody altered HTT subcellular localization, the PRD-targeting intrabodies were seen to increase the turnover rate of HTT [119]. These results reinforce the notion of a strong correlation between the structural domains targeted by each intrabody and their mechanism of neuroprotection. Fragment antibodies VL 12.3 and Haap1 were also employed to investigate the contribution of N-terminus and PRD domains to HD pathology in vivo using five different HD mouse models. While VL 12.3 showed no significant effects on one model, and increased mortality in another, Haap1 alleviated HD neuropathology in all the five animal models tested, including prolonged lifespan in one model [120].

Finally, the scFv-EM48, which targets the C-terminus of human mutant HTT exon 1, also showed promising results in an HD mouse model, as decreased formation of neuropil aggregates and cognitive HD-like symptoms [114]. In conjunction with data obtained with antibody fragments targeting the $\mathrm{N}$-terminus, the polyQ domain, and the PRD domain, these data indicate that all domains within HTT exon 1 play a role in mutant HTT aggregation and toxicity. When used as an intrabody, scFv-EM48 also suppressed the toxicity of mutant HTT in HEK293 cells. The ability of this antibody fragment to increase the ubiquitination and consequent degradation of cytoplasmatic HTT suggests that scFv-EM48 acts by promoting the cytoplasmic clearance of mutant HTT thereby preventing its accumulation. 


\subsection{Prion Diseases}

Prion diseases are characterized by the brain accumulation of aggregated and neurotoxic forms of the prion protein $(\mathrm{PrP})$. Under physiological conditions, $\mathrm{PrP}$ presents as a $\sim 24 \mathrm{kDa}$ transmembrane protein that exerts a number of functions, such as metal ion hemostasis and cell adhesion [121]. On the other hand, in diseased brains, it converts into a beta-sheet-rich confirmation named $\operatorname{PrP}^{\mathrm{sc}}$ (i.e., the scrapie isoform), which forms both soluble oligomers and amyloid fibrils [122-124]. Importantly, $\operatorname{PrP}^{\mathrm{sc}}$ is known to catalyze the conversion of harmless PrP molecules into the aggregation-prone conformation $\mathrm{PrPsc}$, thus conferring to Prion diseases their unique infectious nature [123]. Finding molecules capable of inhibiting either the formation or the toxicity of $\mathrm{PrP}^{\mathrm{sc}}$ aggregates, including soluble oligomers, has been a major goal in the prion diseases field, as a way to provide a disease-modifying therapy for patients. In this regard, some fragment antibodies have been selected that display promising inhibitory activity on $\mathrm{PrP}^{\mathrm{sc}}$ oligomerization and fibrillization both in vitro and in cellular models $[125,126]$.

In 2001, Peretz et al. reported the Fab antibody fragment D18, which binds to an epitope within residues 132-156 in helix 1 of the Prion protein in its native conformation, a region thought to contribute to $\mathrm{PrP}^{\mathrm{sc}}$ assembly and prion elongation. Although the aggregation states targeted by D18 have not yet been identified experimentally, D18 was found to inhibit prion elongation in cultured mouse neuroblastoma cells infected with $\operatorname{PrP}^{\mathrm{sc}}$ [126]. Subsequently, Campana et al. (2009) engineered scFv-D18 from Fab-D18 and used in silico tools to create a structural model of scFv-D18 bound to PrP. In that model, PrP residue Arg151 was seen to be key in the interaction with the antibody fragment, by anchoring $\operatorname{PrP}$ to the cavity formed on antigen binding site of the scFv [127].

More recently, Fujita et al. (2011) cloned the variable region of mAb 3S9-previously shown to inhibit $\mathrm{PrP}^{\mathrm{sc}}$ accumulation in cell lines infected with mouse-adapted scrapie strains [128,129]—into the scaffold of a scFv antibody. The resulting antibody, named scFv-3S9, recognized an epitope containing Tyr154 in the helix 1 of PrP. When injected into mice brains, Prion-infected cells expressing scFv-3S9 presented less Prion pathology than infected cells not expressing this scFv [128].

Lastly, Sonati and coworkers (2013) used a panel composed of full-length antibodies and antibody fragments (Fab and scFv) directed to either the globular domain or the flexible tail on PrP, to investigate the role of these regions in oligomerization and neurotoxicity. Results generated on cerebellar organotypic cultured slices showed that both domains are required for toxicity, as the flexible tail acquires oxidative stress-mediated toxicity upon undergoing a conformational change originated from the globular domain [130]. This comprehensive work reinforced the notion that antibody-based therapeutic developments against Prion diseases must include a detailed analysis of the targeted structural epitope of each antibody candidate as well as the molecular and clinical outcomes of targeting these epitopes.

\section{Concluding Remarks}

Increased knowledge about the aggregation pathways and conformations of the toxic aggregate species relevant to CNS amyloidoses has been obtained with the use of fragment antibodies, in particular $\mathrm{Fab}, \mathrm{scFv}$, and $\mathrm{VHH}$ (Table 1). As technologies for engineering fragment antibodies are constantly improving, the perspective for the generation of novel fragment antibodies with high selectivity for toxic oligomeric conformations as diagnostic and/or therapeutic candidates for CNS amyloidoses, is also rising.

Methodologies for rational $\mathrm{A} \beta$-targeting antibody design have been reviewed (e.g., Plotkin and Cashman, 2020 [131]). For example, just as our group has successfully generated full-length IgGs with selectivity for $A \beta O$ s over monomers and fibrils [132], rational immunization with specific toxic $\mathrm{A} \beta \mathrm{O}$ species can be employed, followed by conversion of the resulting anti- $\mathrm{A} \beta \mathrm{O} \operatorname{IgG}$ to an antibody fragment. Alternatively, specific toxic $\mathrm{A} \beta \mathrm{O}$ species can be utilized in rational bio-panning of antibody fragment libraries. These specific $\mathrm{A} \beta \mathrm{O}$ species can be generated by size-based separation methods (reviewed in [12]) or by utilizing specific A $\beta$ monomeric proteoforms ([133,134]) and can be stabilized by various methods. For example, chemical crosslinking via DFDNB (1,5-difluoro-2,4-dinitrobenzene) 
has been shown to stabilize high molecular weight $\mathrm{A} \beta \mathrm{O}$ s that exhibit toxicity in cell cultures and in vivo [135]. Alternatively, computational prediction of regions present on the surface of toxic oligomeric species is emerging as an additional strategy for rational identification of target species [136].

We envision that the use of fragment antibodies in structural studies aimed to unravel the molecular mechanisms of protein aggregation and related toxicity has a strong potential to make unique contributions to the field. In conjunction with CDR mapping and the detailed analysis of the assembly selectivity of each fragment antibody described, this approach may significantly improve our knowledge regarding key atomic contacts between antibodies and toxic oligomers, and as a consequence, the structural moieties that confer toxicity to amyloid oligomers. These advances could enhance the field's capability of engineering antibody fragments able to selectively target neurotoxic aggregates amongst a multitude of oligomeric assemblies co-existing in diseased human tissue. Even in a likely case in which different oligomeric species contribute to neurotoxicity, and thus a single, highly specific antibody would not able to fully neutralize the pathogenic cascade, a therapeutic strategy based on the combination of multiple oligomer-selective antibody fragments directed against different species could be employed to circumvent this issue.

The cognitive benefit and lowering of multiple AD markers reported in AD patients treated with the antibody aducanumab (Biogen) - a monoclonal IgG that preferentially targets aggregated $A \beta[137,138]$ — has brought hope, reinforcing the notion that selectively targeting neurotoxic aggregates would guide the field toward disease-modifying treatments against brain amyloidosis. Indeed, the FDA has recently granted aducanumab priority review [139]. However, there is still room for improvement in the field as the therapeutic benefits of aducanumab were only apparent following a re-analysis of the phase three trials that were initially halted due to a lack of efficacy [138]. In our view, this improvement will stem from the development of antibodies even more selective to neurotoxic oligomeric assemblies. In this context, detailed structural information on these toxic oligomers will be invaluable to the targeted design of new oligomer-selective fragment antibodies with improved specificity and clinical outcomes.

Author Contributions: All authors have read and agree to the published version of the manuscript. Conceptualization, A.L.B.B., R.M.C. and A.S.; data curation, A.L.B.B., R.M.C. and E.N.C.; writing-original draft preparation, A.L.B.B., R.M.C. and A.S.; writing-review and editing, E.N.C., W.L.K. and A.S.; supervision, A.S. All authors have read and agreed to the published version of the manuscript.

Funding: This research was funded by FAPESP (Grant 2014/25681-3 to AS), CNPq (Pre-Doctoral fellowship to ALBB), CAPES (Pre-Doctoral fellowship to RMC) and the NIH (1RF1AG063903 to WLK).

Conflicts of Interest: The authors declare no conflict of interest. The funders had no role in the design of the study; in the collection, analyses, or interpretation of data; in the writing of the manuscript, or in the decision to publish the results.

$\begin{array}{ll}\text { Abbreviations } \\ \text { AD } & \text { Alzheimer's Disease } \\ \text { A } \beta & \text { Amyloid- } \beta \\ \text { A } \beta \text { Os } & \text { Amyloid- } \beta \text { Peptide Oligomers } \\ \text { CDR } & \text { Complementary-determining Region } \\ \text { CNS } & \text { Central Nervous System } \\ \text { Fab } & \text { Fragment Antigen-Binding } \\ \text { Fc } & \text { Fragment Crystallizable } \\ \mathrm{HD} & \text { Huntington's Disease } \\ \mathrm{HTT} & \text { Huntingtin Protein } \\ \mathrm{IgG} & \text { Immunoglobulin G } \\ \mathrm{mAbs} & \text { Monoclonal Antibodies } \\ \mathrm{NAC} & \text { Nonamyloid Component } \\ \mathrm{PD} & \text { Parkinson's Disease } \\ \mathrm{PrP} & \text { Cellular Prion Protein } \\ \mathrm{PrPs} & \text { Scrapie Prion Protein } \\ \mathrm{scFv} & \text { Single-chain Variable Fragment }\end{array}$




\section{References}

1. Chiti, F.; Dobson, C.M. Protein Misfolding, Amyloid Formation, and Human Disease: A Summary of Progress Over the Last Decade. Annu. Rev. Biochem. 2017, 86, 27-68. [CrossRef]

2. Bleiholder, C.; Dupuis, N.F.; Wyttenbach, T.; Bowers, M.T. Ion mobilityg-mass spectrometry reveals a conformational conversion from random assembly to $\beta$-sheet in amyloid fibril formation. Nat. Chem. 2011, 3, 172-177. [CrossRef]

3. Lomont, J.P.; Rich, K.L.; Maj, M.; Ho, J.-J.; Ostrander, J.S.; Zanni, M.T. Spectroscopic Signature for Stable $\beta$-Amyloid Fibrils versus $\beta$-Sheet-Rich Oligomers. J. Phys. Chem. B 2018, 122, 144-153. [CrossRef]

4. Lu, J.-X.; Qiang, W.; Yau, W.-M.; Schwieters, C.D.; Meredith, S.C.; Tycko, R. Molecular structure of $\beta$-amyloid fibrils in Alzheimer's disease brain tissue. Cell 2013, 154, 1257-1268. [CrossRef]

5. Kayed, R.; Head, E.; Thompson, J.L.; McIntire, T.M.; Milton, S.C.; Cotman, C.W.; Glabel, C.G. Common structure of soluble amyloid oligomers implies common mechanism of pathogenesis. Science 2003, 300, 486-489. [CrossRef]

6. Chiti, F.; Webster, P.; Taddei, N.; Clark, A.; Stefani, M.; Ramponi, G.; Dobson, C.M. Designing conditions for in vitro formation of amyloid protofilaments and fibrils. Proc. Natl. Acad. Sci. USA 1999, 96, 3590-3594. [CrossRef]

7. Bucciantini, M.; Giannoni, E.; Chiti, F.; Baroni, F.; Taddei, N.; Ramponi, G.; Dobson, C.M.; Stefani, M. Inherent toxicity of aggregates implies a common mechanism for protein misfolding diseases. Nature 2002, 416, 507-511. [CrossRef]

8. Dobson, C.M. The structural basis of protein folding and its links with human disease. Proc. Philos. Trans. R. Soc. B Biol. Sci. 2001, 356, 133-145. [CrossRef]

9. Kelly, J.W. The alternative conformations of amyloidogenic proteins and their multi-step assembly pathways. Curr. Opin. Struct. Biol. 1998, 8, 101-106. [CrossRef]

10. Hardy, J.A.; Higgins, G.A. Alzheimer's disease: The amyloid cascade hypothesis. Science 1992, 256, 184-185. [CrossRef]

11. Vieira, M.N.N.; Forny-Germano, L.; Saraiva, L.M.; Sebollela, A.; Martinez, A.M.B.; Houzel, J.C.; De Felice, F.G.; Ferreira, S.T. Soluble oligomers from a non-disease related protein mimic A $\beta$-induced tau hyperphosphorylation and neurodegeneration. J. Neurochem. 2007, 103, 736-748. [CrossRef]

12. Cline, E.N.; Bicca, M.A.; Viola, K.L.; Klein, W.L. The Amyloid- $\beta$ Oligomer Hypothesis: Beginning of the Third Decade. J. Alzheimer's Dis. 2018, 64, S567-S610. [CrossRef]

13. Valera, E.; Spencer, B.; Masliah, E. Immunotherapeutic Approaches Targeting Amyloid- $\beta$, $\alpha$-Synuclein, and Tau for the Treatment of Neurodegenerative Disorders. Neurotherapeutics 2016, 13, 179-189. [CrossRef]

14. Bittar, A.; Bhatt, N.; Kayed, R. Advances and considerations in AD tau-targeted immunotherapy. Neurobiol. Dis. 2020, 134, 104707. [CrossRef]

15. Choi, M.L.; Gandhi, S. Crucial role of protein oligomerization in the pathogenesis of Alzheimer's and Parkinson's diseases. FEBS J. 2018, 285, 3631-3644. [CrossRef]

16. Gong, Y.; Chang, L.; Viola, K.L.; Lacor, P.N.; Lambert, M.P.; Finch, C.E.; Krafft, G.A.; Klein, W.L. Alzheimer's disease-affected brain: Presence of oligomeric A ligands (ADDLs) suggests a molecular basis for reversible memory loss. Proc. Natl. Acad. Sci. USA 2003, 100, 10417-10422. [CrossRef]

17. Shankar, G.M.; Li, S.; Mehta, T.H.; Garcia-Munoz, A.; Shepardson, N.E.; Smith, I.; Brett, F.M.; Farrell, M.A.; Rowan, M.J.; Lemere, C.A.; et al. Amyloid- $\beta$ protein dimers isolated directly from Alzheimer's brains impair synaptic plasticity and memory. Nat. Med. 2008, 14, 837-842. [CrossRef]

18. Lambert, M.P.; Barlow, A.K.; Chromy, B.A.; Edwards, C.; Freed, R.; Liosatos, M.; Morgan, T.E.; Rozovsky, I.; Trommer, B.; Viola, K.L.; et al. Diffusible, nonfibrillar ligands derived from A 1-42 are potent central nervous system neurotoxins. Proc. Natl. Acad. Sci. USA 1998, 95, 6448-6453. [CrossRef]

19. Theillet, F.X.; Binolfi, A.; Bekei, B.; Martorana, A.; Rose, H.M.; Stuiver, M.; Verzini, S.; Lorenz, D.; Van Rossum, M.; Goldfarb, D.; et al. Structural disorder of monomeric $\alpha$-synuclein persists in mammalian cells. Nature 2016. [CrossRef]

20. Spillantini, M.G.; Schmidt, M.L.; Lee, V.M.Y.; Trojanowski, J.Q.; Jakes, R.; Goedert, M. Alpha-synuclein in Lewy bodies. Nature 1997, 388, 839-840. [CrossRef]

21. Hatters, D.M. Protein misfolding inside cells: The case of Huntingtin and Huntington's disease. IUBMB Life 2008, 60, 724-728. [CrossRef] 
22. Imarisio, S.; Carmichael, J.; Korolchuk, V.; Chen, C.W.; Saiki, S.; Rose, C.; Krishna, G.; Davies, J.E.; Ttofi, E.; Underwood, B.R.; et al. Huntington's disease: From pathology and genetics to potential therapies. Biochem. J. 2008, 412, 191-209. [CrossRef]

23. Grassmann, A.; Wolf, H.; Hofmann, J.; Graham, J.; Vorberg, I. Cellular aspects of prion replication in vitro. Viruses 2012, 5, 374-405. [CrossRef]

24. Soto, C.; Satani, N. The intricate mechanisms of neurodegeneration in prion diseases. Trends Mol. Med. 2011, 17, 14-24. [CrossRef]

25. Rabinovici, G.D.; Carrillo, M.C.; Forman, M.; DeSanti, S.; Miller, D.S.; Kozauer, N.; Petersen, R.C.; Randolph, C.; Knopman, D.S.; Smith, E.E.; et al. Multiple comorbid neuropathologies in the setting of Alzheimer's disease neuropathology and implications for drug development. Alzheimer's Dement. Transl. Res. Clin. Interv. 2017, 3, 83-91. [CrossRef]

26. Visanji, N.P.; Lang, A.E.; Kovacs, G.G. Beyond the synucleinopathies: Alpha synuclein as a driving force in neurodegenerative comorbidities. Transl. Neurodegener. 2019, 8, 28. [CrossRef]

27. Goure, W.F.; Krafft, G.A.; Jerecic, J.; Hefti, F. Targeting the proper amyloid-beta neuronal toxins: A path forward for Alzheimer's disease immunotherapeutics. Alzheimer's Res. Ther. 2014, 6, 42. [CrossRef]

28. Sengupta, U.; Nilson, A.N.; Kayed, R. The Role of Amyloid- $\beta$ Oligomers in Toxicity, Propagation, and Immunotherapy. EBioMedicine 2016, 6, 42-49. [CrossRef]

29. Oertel, W.H. Recent advances in treating Parkinson's disease. F1000Research 2017, 6, 260. [CrossRef]

30. Masnata, M.; Cicchetti, F. The evidence for the spread and seeding capacities of the mutant huntingtin protein in in vitro systems and their therapeutic implications. Front. Neurosci. 2017, 11, 647. [CrossRef]

31. Jankovic, J.; Rousseaux, M.W.C.; Shulman, J.M. Progress toward an integrated understanding of Parkinson's disease. F1000Research 2017, 6, 1121.

32. Velayudhan, L.; Ffytche, D.; Ballard, C.; Aarsland, D. New Therapeutic Strategies for Lewy Body Dementias. Curr. Neurol. Neurosci. Rep. 2017, 17, 68. [CrossRef]

33. Zella, S.M.A.; Metzdorf, J.; Ciftci, E.; Ostendorf, F.; Muhlack, S.; Gold, R.; Tönges, L. Emerging Immunotherapies for Parkinson Disease. Neurol. Ther. 2019, 8, 29-44. [CrossRef]

34. De Genst, E.; Messer, A.; Dobson, C.M. Antibodies and protein misfolding: From structural research tools to therapeutic strategies. Biochim. Biophys. Acta 2014, 8, 29-44. [CrossRef]

35. Villar-Piqué, A.; Lopes da Fonseca, T.; Outeiro, T.F. Structure, function and toxicity of alpha-synuclein: the Bermuda triangle in synucleinopathies. J. Neurochem. 2016, 139, 240-255. [CrossRef]

36. Hoffner, G.; Djian, P. Polyglutamine Aggregation in Huntington Disease: Does Structure Determine Toxicity? Mol. Neurobiol. 2015, 52, 1297-1314. [CrossRef]

37. Carter, L.; Kim, S.J.; Schneidman-Duhovny, D.; Stöhr, J.; Poncet-Montange, G.; Weiss, T.M.; Tsuruta, H.; Prusiner, S.B.; Sali, A. Prion Protein-Antibody Complexes Characterized by Chromatography-Coupled Small-Angle X-Ray Scattering. Biophys. J. 2015, 109, 793-805. [CrossRef]

38. Bates, A.; Power, C.A. David vs. Goliath: The Structure, Function, and Clinical Prospects of Antibody Fragments. Antibodies 2019, 8, 28. [CrossRef]

39. Bélanger, K.; Iqbal, U.; Tanha, J.; MacKenzie, R.; Moreno, M.; Stanimirovic, D. Single-Domain Antibodies as Therapeutic and Imaging Agents for the Treatment of CNS Diseases. Antibodies 2019, 8, 27. [CrossRef]

40. Nicoll, J.A.; Wilkinson, D.; Holmes, C.; Steart, P.; Markham, H.; Weller, R.O. Neuropathology of human Alzheimer disease after immunization with amyloid-beta peptide: a case report. Nat Med 2003, 9, 448-452. [CrossRef]

41. Ferrer, I.; Rovira, M.B.; Guerra, M.L.S.; Rey, M.J.; Costa-Jussá, F. Neuropathology and Pathogenesis of Encephalitis following Amyloid $\beta$ Immunization in Alzheimer's Disease. Brain Pathol. 2004, 14, 11-20. [CrossRef]

42. Gilman, S.; Koller, M.; Black, R.S.; Jenkins, L.; Griffith, S.G.; Fox, N.C.; Eisner, L.; Kirby, L.; Boada Rovira, M.; Forette, F.; et al. Clinical effects of $A \beta$ immunization (AN1792) in patients with AD in an interrupted trial. Neurology 2005, 64, 1553-1562. [CrossRef]

43. Lee, M.; Bard, F.; Johnson-Wood, K.; Lee, C.; Hu, K.; Griffith, S.G.; Black, R.S.; Schenk, D.; Seubert, P. A $\beta 42$ immunization in Alzheimer's disease generates A $\beta$ N-terminal antibodies. Ann. Neurol. 2005, 28, 430-435. [CrossRef]

44. Strohl, W.R.; Strohl, L.M. Therapeutic Antibody Engineering: Current and Future Advances Driving the Strongest Growth Area in the Pharmaceutical Industry; Woodhead Publishing: Cambridge, UK, 2012; ISBN 9781907568374. 
45. Meyer-Luehmann, M.; Spires-Jones, T.L.; Prada, C.; Garcia-Alloza, M.; De Calignon, A.; Rozkalne, A.; Koenigsknecht-Talboo, J.; Holtzman, D.M.; Bacskai, B.J.; Hyman, B.T. Rapid appearance and local toxicity of amyloid- $\beta$ plaques in a mouse model of Alzheimer's disease. Nature 2008, 451, 720-724. [CrossRef]

46. Esquerda-Canals, G.; Martí-Clúa, J.; Villegas, S. Pharmacokinetic parameters and mechanism of action of an efficient anti-A $\beta$ single chain antibody fragment. PLoS One 2019, 14, e0217793. [CrossRef]

47. Manoutcharian, K.; Perez-Garmendia, R.; Gevorkian, G. Recombinant Antibody Fragments for Neurodegenerative Diseases. Curr. Neuropharmacol. 2016, 5, 779-788. [CrossRef]

48. Holliger, P.; Hudson, P.J. Engineered antibody fragments and the rise of single domains. Nat. Biotechnol. 2005, 23, 1126-1136. [CrossRef]

49. Pain, C.; Dumont, J.; Dumoulin, M. Camelid single-domain antibody fragments: Uses and prospects to investigate protein misfolding and aggregation, and to treat diseases associated with these phenomena. Biochimie 2015, 111, 82-106. [CrossRef]

50. Chia, K.Y.; Ng, K.Y.; Koh, R.Y.; Chye, S.M. Single-chain Fv Antibodies for Targeting Neurodegenerative Diseases. CNS Neurol. Disord. 2018, 17, 671-679. [CrossRef]

51. Chatterjee, D.; Kordower, J.H. Immunotherapy in Parkinson's disease: Current status and future directions. Neurobiol. Dis. 2019, 132, 104587. [CrossRef]

52. Messer, A.; Butler, D.C. Optimizing intracellular antibodies (intrabodies/nanobodies) to treat neurodegenerative disorders. Neurobiol. Dis. 2020, 134, 104619. [CrossRef]

53. Nelson, A.L.; Reichert, J.M. Development trends for therapeutic antibody fragments. Nat. Biotechnol. 2009, 27, 331-337. [CrossRef]

54. Monnier, P.; Vigouroux, R.; Tassew, N. In Vivo Applications of Single Chain Fv (Variable Domain) (scFv) Fragments. Antibodies 2013, 2, 193-208. [CrossRef]

55. Alspach, E.; Lussier, D.M.; Miceli, A.P.; Kizhvatov, I.; DuPage, M.; Luoma, A.M.; Meng, W.; Lichti, C.F.; Esaulova, E.; Vomund, A.N.; et al. MHC-II neoantigens shape tumour immunity and response to immunotherapy. Nature 2019, 574, 696-701. [CrossRef]

56. Ewert, S.; Huber, T.; Honegger, A.; Plückthun, A. Biophysical properties of human antibody variable domains. J. Mol. Biol. 2003, 325, 531-553. [CrossRef]

57. Nelson, A.L. Antibody fragments: Hope and hype. MAbs 2010, 2, 77-83. [CrossRef]

58. Rose, A.S.; Hildebrand, P.W. NGL Viewer: A web application for molecular visualization. Nucleic Acids Res. 2015, 43, W576-W579. [CrossRef]

59. Abbas, A.K.; Lichtman, A.H. Cellular and Molecular Immunology; Saunders: Philadelphia, PA, USA, 2014; ISBN 9780323315937.

60. Wörn, A.; Plückthun, A. Stability engineering of antibody single-chain Fv fragments. J. Mol. Biol. 2001, 305, 989-1010. [CrossRef]

61. Harmsen, M.M.; De Haard, H.J. Properties, production, and applications of camelid single-domain antibody fragments. Appl. Microbiol. Biotechnol. 2007, 77, 13-22. [CrossRef]

62. Paul, W.E. Fundamental Immunology; LWW: Philadelphia, PA, USA, 2012; ISBN 9781451117837.

63. Mitchell, L.S.; Colwell, L.J. Comparative analysis of nanobody sequence and structure data. Proteins Struct. Funct. Bioinforma. 2018, 86, 697-706. [CrossRef]

64. Velasco, P.T.; Heffern, M.C.; Sebollela, A.; Popova, I.A.; Lacor, P.N.; Lee, K.B.; Sun, X.; Tiano, B.N.; Viola, K.L.; Eckermann, A.L.; et al. Synapse-binding subpopulations of Abeta oligomers sensitive to peptide assembly blockers and scFv antibodies. ACS Chem Neurosci 2012, 3, 972-981. [CrossRef]

65. Sebollela, A.; Cline, E.N.; Popova, I.; Luo, K.; Sun, X.; Ahn, J.; Barcelos, M.A.; Bezerra, V.N.; Lyra e Silva, N.M.; Patel, J.; et al. A human $\mathrm{scFv}$ antibody that targets and neutralizes high molecular weight pathogenic amyloid- $\beta$ oligomers. J. Neurochem. 2017, 142, 934-947. [CrossRef]

66. Zhang, Y.; Chen, X.; Liu, J.; Zhang, Y. The protective effects and underlying mechanism of an anti-oligomeric A 342 single-chain variable fragment antibody. Neuropharmacology 2015, 99, 387-395. [CrossRef]

67. Zhang, Y.; Sun, Y.; Huai, Y.; Zhang, Y.J. Functional Characteristics and Molecular Mechanism of a New scFv Antibody Against A $\beta 42$ Oligomers and Immature Protofibrils. Mol. Neurobiol. 2015, 52, 1269-1281. [CrossRef]

68. Zhang, X.; Huai, Y.; Cai, J.; Song, C.; Zhang, Y. Novel antibody against oligomeric amyloid- $\beta$ : Insight into factors for effectively reducing the aggregation and cytotoxicity of amyloid- $\beta$ aggregates. Int. Immunopharmacol. 2019, 67, 176-185. [CrossRef] 
69. Wang, J.; Wang, J.; Li, N.; Ma, J.; Gu, Z.; Yu, L.; Fu, X.; Liu, X. Effects of an amyloid-beta 1-42 oligomers antibody screened from a phage display library in APP/PS1 transgenic mice. Brain Res. 2016, 1635, 169-179. [CrossRef]

70. Zameer, A.; Kasturirangan, S.; Emadi, S.; Nimmagadda, S. V.; Sierks, M.R. Anti-oligomeric A $\beta$ Single-chain Variable Domain Antibody Blocks A $\beta$-induced Toxicity Against Human Neuroblastoma Cells. J. Mol. Biol. 2008, 384, 917-928. [CrossRef]

71. Kasturirangan, S.; Li, L.; Emadi, S.; Boddapati, S.; Schulz, P.; Sierks, M.R. Nanobody specific for oligomeric beta-amyloid stabilizes nontoxic form. Neurobiol. Aging 2012, 33, 1320-1328. [CrossRef]

72. Yang, J.; Pattanayak, A.; Song, M.; Kou, J.; Taguchi, H.; Paul, S.; Ponnazhagan, S.; Lalonde, R.; Fukuchi, K.I. Muscle-directed anti-A $\beta$ Single-Chain Antibody Delivery Via AAV1 reduces cerebral A $\beta$ load in an Alzheimer's disease mouse model. J. Mol. Neurosci. 2013, 49, 277-288. [CrossRef]

73. Krishnaswamy, S.; Lin, Y.; Rajamohamedsait, W.J.; Rajamohamedsait, H.B.; Krishnamurthy, P.; Sigurdsson, E.M. Antibody-derived in Vivo imaging of tau pathology. J. Neurosci. 2014, 34, 16835-16850. [CrossRef]

74. Tian, H.; Davidowitz, E.; Lopez, P.; He, P.; Schulz, P.; Moe, J.; Sierks, M.R. Isolation and characterization of antibody fragments selective for toxic oligomeric tau. Neurobiol. Aging 2015, 36, 1342-1355. [CrossRef]

75. Nisbet, R.M.; Van Der Jeugd, A.; Leinenga, G.; Evans, H.T.; Janowicz, P.W.; Götz, J. Combined effects of scanning ultrasound and a tau-specific single chain antibody in a tau transgenic mouse model. Brain 2017, 140, 1220-1230. [CrossRef]

76. Emadi, S.; Barkhordarian, H.; Wang, M.S.; Schulz, P.; Sierks, M.R. Isolation of a Human Single Chain Antibody Fragment Against Oligomeric $\alpha$-Synuclein that Inhibits Aggregation and Prevents $\alpha$-Synuclein-induced Toxicity. J. Mol. Biol. 2007, 368, 1132-1144. [CrossRef]

77. Emadi, S.; Kasturirangan, S.; Wang, M.S.; Schulz, P.; Sierks, M.R. Detecting morphologically distinct oligomeric forms of $\alpha$-synuclein. J. Biol. Chem. 2009, 284, 11048-11058. [CrossRef]

78. Butler, D.C.; Joshi, S.N.; De Genst, E.; Baghel, A.S.; Dobson, C.M.; Messer, A. Bifunctional anti-non-amyloid component $\alpha$-Synuclein nanobodies are protective in situ. PLoS ONE 2016, 11, e0165964. [CrossRef]

79. Spencer, B.; Emadi, S.; Desplats, P.; Eleuteri, S.; Michael, S.; Kosberg, K.; Shen, J.; Rockenstein, E.; Patrick, C.; Adame, A.; et al. ESCRT-mediated uptake and degradation of brain-targeted $\alpha$-synuclein single chain antibody attenuates neuronal degeneration in vivo. Mol. Ther. 2014, 22, 1753-1767. [CrossRef]

80. Zhang, X.; Sun, X.X.; Xue, D.; Liu, D.G.; Hu, X.Y.; Zhao, M.; Yang, S.G.; Yang, Y.; Xia, Y.J.; Wang, Y.; et al. Conformation-dependent $\mathrm{scFv}$ antibodies specifically recognize the oligomers assembled from various amyloids and show colocalization of amyloid fibrils with oligomers in patients with amyloidoses. Biochim. Biophys. Acta 2011, 1814, 1703-1712. [CrossRef]

81. Benilova, I.; Karran, E.; De Strooper, B. The toxic A $\beta$ oligomer and Alzheimer's disease: An emperor in need of clothes. Nat. Neurosci. 2012, 15, 349-357. [CrossRef]

82. Haass, C.; Selkoe, D.J. Soluble protein oligomers in neurodegeneration: Lessons from the Alzheimer's amyloid $\beta$-peptide. Nat. Rev. Mol. Cell Biol. 2007, 8, 101-112. [CrossRef]

83. Solórzano-Vargas, R.S.; Vasilevko, V.; Acero, G.; Ugen, K.E.; Martinez, R.; Govezensky, T.; Vazquez-Ramirez, R.; Kubli-Garfias, C.; Cribbs, D.H.; Manoutcharian, K.; et al. Epitope mapping and neuroprotective properties of a human single chain FV antibody that binds an internal epitope of amyloid-beta 1-42. Mol. Immunol. 2008. [CrossRef]

84. Williams, S.M.; Schulz, P.; Sierks, M.R. Oligomeric $\alpha$-synuclein and $\beta$-amyloid variants as potential biomarkers for Parkinson's and Alzheimer's diseases. Eur. J. Neurosci. 2016. [CrossRef]

85. Tiller, K.E.; Li, L.; Kumar, S.; Julian, M.C.; Garde, S.; Tessier, P.M. Arginine mutations in antibody complementarity-determining regions display context-dependent affinity/specificity trade-offs. J. Biol. Chem. 2017, 45, 881-886. [CrossRef]

86. Das, U.; Hariprasad, G.; Ethayathulla, A.S.; Manral, P.; Das, T.K.; Pasha, S.; Mann, A.; Ganguli, M.; Verma, A.K.; Bhat, R.; et al. Inhibition of protein aggregation: Supramolecular assemblies of Arginine hold the key. PLoS ONE 2007, 2, e1176. [CrossRef]

87. Kawasaki, T.; Onodera, K.; Kamijo, S. Selection of peptide inhibitors of soluble A $\beta 1-42$ oligomer formation by phage display. Biosci. Biotechnol. Biochem. 2010, 74, 2214-2219. [CrossRef]

88. Sellés, M.C.; Fortuna, J.; Cercato, M.; Bitencourt, A.; Souza, A.; Prado, V.; Prado, M.; Sebollela, A.; Arancio, O.; Klein, W.; et al. Neuronal expression of NUsc1, a single-chain variable fragment antibody against Ab oligomers, protects synapses and rescues memory in Alzheimer's disease models. IBRO Rep. 2019, 6, S497. [CrossRef] 
89. Castellani, R.J.; Perry, G.; Tabaton, M. Tau biology, tauopathy, traumatic brain injury, and diagnostic challenges. J. Alzheimer's Dis. 2019, 67, 447-467. [CrossRef]

90. Buée, L.; Bussière, T.; Buée-Scherrer, V.; Delacourte, A.; Hof, P.R. Tau protein isoforms, phosphorylation and role in neurodegenerative disorders. Brain Res. Rev. 2000, 33, 95-130. [CrossRef]

91. Kundel, F.; Hong, L.; Falcon, B.; McEwan, W.A.; Michaels, T.C.T.; Meisl, G.; Esteras, N.; Abramov, A.Y.; Knowles, T.J.P.; Goedert, M.; et al. Measurement of Tau Filament Fragmentation Provides Insights into Prion-like Spreading. ACS Chem. Neurosci. 2018, 9, 1276-1282. [CrossRef]

92. Ising, C.; Gallardo, G.; Leyns, C.E.G.; Wong, C.H.; Jiang, H.; Stewart, F.; Koscal, L.J.; Roh, J.; Robinson, G.O.; Serrano, J.R.; et al. AAV-mediated expression of anti-tau scFvs decreases tau accumulation in a mouse model of tauopathy. J. Exp. Med. 2017, 214, 1227-1238. [CrossRef]

93. Schulz-Schaeffer, W.J. The synaptic pathology of $\alpha$-synuclein aggregation in dementia with Lewy bodies, Parkinson's disease and Parkinson's disease dementia. Acta Neuropathol. 2010, 12, 131-143. [CrossRef]

94. Langston, J.W.; Sastry, S.; Chan, P.; Forno, L.S.; Bolin, L.M.; Di Monte, D.A. Novel $\alpha$-synuclein-immunoreactive proteins in brain samples from the Contursi kindred, Parkinson's, and Alzheimer's disease. Exp. Neurol. 1998, 154, 684-690. [CrossRef]

95. Conway, K.A.; Harper, J.D.; Lansbury, P.T. Fibrils formed in vitro from $\alpha$-synuclein and two mutant forms linked to Parkinson's disease are typical amyloid. Biochemistry 2000, 39, 2552-2563. [CrossRef]

96. Nannenga, B.L.; Zameer, A.; Sierks, M.R. Anti-oligomeric single chain variable domain antibody differentially affects huntingtin and $\alpha$-synuclein aggregates. FEBS Lett. 2008, 582, 517-522. [CrossRef]

97. Kayed, R.; Head, E.; Sarsoza, F.; Saing, T.; Cotman, C.W.; Necula, M.; Margol, L.; Wu, J.; Breydo, L.; Thompson, J.L.; et al. Fibril specific, conformation dependent antibodies recognize a generic epitope common to amyloid fibrils and fibrillar oligomers that is absent in prefibrillar oligomers. Mol. Neurodegener. 2007, 2, 18. [CrossRef]

98. Spencer, B.; Williams, S.; Rockenstein, E.; Valera, E.; Xin, W.; Mante, M.; Florio, J.; Adame, A.; Masliah, E.; Sierks, M.R. $\alpha$-synuclein conformational antibodies fused to penetratin are effective in models of Lewy body disease. Ann. Clin. Transl. Neurol. 2016, 3, 588-606. [CrossRef]

99. Kvam, E.; Nannenga, B.L.; Wang, M.S.; Jia, Z.; Sierks, M.R.; Messer, A. Conformational targeting of fibrillar polyglutamine proteins in live cells escalates aggregation and cytotoxicity. PLoS One 2009, 4, e5727. [CrossRef]

100. Zhou, C.; Emadi, S.; Sierks, M.R.; Messer, A. A human single-chain Fv intrabody blocks aberrant cellular effects of overexpressed $\alpha$-synuclein. Mol. Ther. 2004, 10, 1023-1031. [CrossRef]

101. De Genst, E.J.; Guilliams, T.; Wellens, J.; Day, E.M.; Waudby, C.A.; Meehan, S.; Dumoulin, M.; Hsu, S.T.D.; Cremades, N.; Verschueren, K.H.G.; et al. Structure and properties of a complex of $\alpha$-synuclein and a single-domain camelid antibody. J. Mol. Biol. 2010, 402, 326-343. [CrossRef]

102. Vuchelen, A.; O’Day, E.; De Genst, E.; Pardon, E.; Wyns, L.; Dumoulin, M.; Dobson, C.M.; Christodoulou, J.; Hsu, S.T.D. $1 \mathrm{H}, 13 \mathrm{C}$ and $15 \mathrm{~N}$ assignments of a camelid nanobody directed against human $\alpha$-synuclein. Biomol. NMR Assign. 2009, 3, 231-233. [CrossRef]

103. El-Turk, F.; Newby, F.N.; De Genst, E.; Guilliams, T.; Sprules, T.; Mittermaier, A.; Dobson, C.M.; Vendruscolo, M. Structural Effects of Two Camelid Nanobodies Directed to Distinct C-Terminal Epitopes on $\alpha$-Synuclein. Biochemistry 2016, 55, 3116-3122. [CrossRef]

104. Emamzadeh, F.N. Alpha-synuclein structure, functions, and interactions. J. Res. Med. Sci. 2016, 9, 21-29. [CrossRef]

105. Lynch, S.M.; Zhou, C.; Messer, A. An scFv Intrabody against the Nonamyloid Component of $\alpha$-Synuclein Reduces Intracellular Aggregation and Toxicity. J. Mol. Biol. 2008, 377, 136-147. [CrossRef]

106. Guilliams, T.; El-Turk, F.; Buell, A.K.; O’Day, E.M.; Aprile, F.A.; Esbjörner, E.K.; Vendruscolo, M.; Cremades, N.; Pardon, E.; Wyns, L.; et al. Nanobodies raised against monomeric $\alpha$-synuclein distinguish between fibrils at different maturation stages. J. Mol. Biol. 2013, 425, 2397-2411. [CrossRef]

107. Ross, C.A.; Tabrizi, S.J. Huntington's disease: From molecular pathogenesis to clinical treatment. Lancet Neurol. 2011, 10, 83-98. [CrossRef]

108. Davies, S.W.; Turmaine, M.; Cozens, B.A.; DiFiglia, M.; Sharp, A.H.; Ross, C.A.; Scherzinger, E.; Wanker, E.E.; Mangiarini, L.; Bates, G.P. Formation of neuronal intranuclear inclusions underlies the neurological dysfunction in mice transgenic for the HD mutation. Cell 1997, 90, 537-548. [CrossRef]

109. Lecerf, J.M.; Shirley, T.L.; Zhu, Q.; Kazantsev, A.; Amersdorfer, P.; Housman, D.E.; Messer, A.; Huston, J.S. Human single-chain Fv intrabodies counteract in situ huntingtin aggregation in cellular models of Huntington's disease. Proc. Natl. Acad. Sci. USA 2001, 98, 4764-4769. [CrossRef] 
110. Saudou, F.; Humbert, S. The Biology of Huntingtin. Neuron 2016, 89, 910-926. [CrossRef]

111. Koyuncu, S.; Fatima, A.; Gutierrez-Garcia, R.; Vilchez, D. Proteostasis of huntingtin in health and disease. Int. J. Mol. Sci. 2017, 18, 1568. [CrossRef]

112. De Genst, E.; Chirgadze, D.Y.; Klein, F.A.C.; Butler, D.C.; Matak-Vinković, D.; Trottier, Y.; Huston, J.S.; Messer, A.; Dobson, C.M. Structure of a single-chain Fv bound to the $17 \mathrm{~N}$-terminal residues of huntingtin provides insights into pathogenic amyloid formation and suppression. J. Mol. Biol. 2015, 427, 2166-2178. [CrossRef]

113. Murphy, R.C.; Messer, A. A single-chain Fv intrabody provides functional protection against the effects of mutant protein in an organotypic slice culture model of Huntington's disease. Mol. Brain Res. 2004, 121, 141-145. [CrossRef]

114. Butler, D.C.; Messer, A. Bifunctional anti-huntingtin proteasome-directed intrabodies mediate efficient degradation of mutant huntingtin exon 1 protein fragments. PLoS One 2011, 6, e29199. [CrossRef]

115. Snyder-Keller, A.; McLear, J.A.; Hathorn, T.; Messer, A. Early or late-stage anti-N-terminal huntingtin intrabody gene therapy reduces pathological features in B6.HDR6/1 mice. J. Neuropathol. Exp. Neurol. 2010, 69, 1078-1085. [CrossRef]

116. Khoshnan, A.; Ko, J.; Patterson, P.H. Effects of intracellular expression of anti-huntingtin antibodies of various specificities on mutant huntingtin aggregation and toxicity. Proc. Natl. Acad. Sci. USA 2002, 99, 1002-1007. [CrossRef]

117. Southwell, A.L.; Khoshnan, A.; Dunn, D.E.; Bugg, C.W.; Lo, D.C.; Patterson, P.H. Intrabodies binding the proline-rich domains of mutant Huntingtin increase its turnover and reduce neurotoxicity. J. Neurosci. 2008, 28, 9013-9020. [CrossRef]

118. Shimizu, Y.; Kaku-Ushiki, Y.; Iwamaru, Y.; Muramoto, T.; Kitamoto, T.; Yokoyama, T.; Mohri, S.; Tagawa, Y. A novel anti-prion protein monoclonal antibody and its single-chain fragment variable derivative with ability to inhibit abnormal prion protein accumulation in cultured cells. Microbiol. Immunol. 2010, 54, 112-121. [CrossRef]

119. Wang, C.E.; Zhou, H.; McGuire, J.R.; Cerullo, V.; Lee, B.; Li, S.H.; Li, X.J. Suppression of neuropil aggregates and neurological symptoms by an intracellular antibody implicates the cytoplasmic toxicity of mutant huntingtin. J. Cell Biol. 2008, 181, 803-816. [CrossRef]

120. Southwell, A.L.; Ko, J.; Patterson, P.H. Intrabody gene therapy ameliorates motor, cognitive, and neuropathological symptoms in multiple mouse models of Huntington's disease. J. Neurosci. 2009, 29, 13589-13602. [CrossRef]

121. Biasini, E.; Turnbaugh, J.A.; Unterberger, U.; Harris, D.A. Prion protein at the crossroads of physiology and disease. Trends Neurosci. 2012, 35, 92-103. [CrossRef]

122. Martins, S.M.; Frosoni, D.J.; Martinez, A.M.B.; De Felice, F.G.; Ferreira, S.T. Formation of soluble oligomers and amyloid fibrils with physical properties of the scrapie isoform of the prion protein from the C-terminal domain of recombinant murine prion protein mPrP-(121-231). J. Biol. Chem. 2006, 281, 26121-26128. [CrossRef]

123. Aguzzi, A.; Lakkaraju, A.K.K. Cell Biology of Prions and Prionoids: A Status Report. Trends Cell Biol. 2016, 26, 40-51. [CrossRef]

124. Pan, K.M.; Baldwin, M.; Nguyen, J.; Gasset, M.; Serban, A.; Groth, D.; Mehlhorn, I.; Huang, Z.; Fletterick, R.J.; Cohen, F.E.; et al. Conversion of $\alpha$-helices into $\beta$-sheets features in the formation of the scrapie prion proteins. Proc. Natl. Acad. Sci. USA 1993. [CrossRef]

125. Donofrio, G.; Heppner, F.L.; Polymenidou, M.; Musahl, C.; Aguzzi, A. Paracrine Inhibition of Prion Propagation by Anti-PrP Single-Chain Fv Miniantibodies. J. Virol. 2005. [CrossRef]

126. Peretz, D.; Williamson, R.A.; Kaneko, K.; Vergara, J.; Leclerc, E.; Schmitt-Ulms, G.; Mehlhorn, I.R.; Legname, G.; Wormald, M.R.; Rudd, P.M.; et al. Antibodies inhibit prion propagation and clear cell cultures of prion infectivity. Nature 2001, 412, 739-743. [CrossRef]

127. Campana, V.; Zentilin, L.; Mirabile, I.; Kranjc, A.; Casanova, P.; Giacca, M.; Prusiner, S.B.; Legname, G.; Zurzolo, C. Development of antibody fragments for immunotherapy of prion diseases. Biochem. J. 2009, 418, 507-515. [CrossRef]

128. Fujita, K.; Yamaguchi, Y.; Mori, T.; Muramatsu, N.; Miyamoto, T.; Yano, M.; Miyata, H.; Ootsuyama, A.; Sawada, M.; Matsuda, H.; et al. Effects of a brain-engraftable microglial cell line expressing anti-prion scFv antibodies on survival times of mice infected with scrapie prions. Cell. Mol. Neurobiol. 2011, 31, 999-1008. [CrossRef]

129. Miyamoto, K.; Nakamura, N.; Aosasa, M.; Nishida, N.; Yokoyama, T.; Horiuchi, H.; Furusawa, S.; Matsuda, H. Inhibition of prion propagation in scrapie-infected mouse neuroblastoma cell lines using mouse monoclonal antibodies against prion protein. Biochem. Biophys. Res. Commun. 2005, 335, 197-204. [CrossRef] 
130. Sonati, T.; Reimann, R.R.; Falsig, J.; Baral, P.K.; O'Connor, T.; Hornemann, S.; Yaganoglu, S.; Li, B.; Herrmann, U.S.; Wieland, B.; et al. The toxicity of antiprion antibodies is mediated by the flexible tail of the prion protein. Nature 2013, 501, 102-106. [CrossRef]

131. Plotkin, S.S.; Cashman, N.R. Passive immunotherapies targeting A $\beta$ and tau in Alzheimer's disease. Neurobiol. Dis. 2020, 144, 26. [CrossRef]

132. Lambert, M.P.; Velasco, P.T.; Chang, L.; Viola, K.L.; Fernandez, S.; Lacor, P.N.; Khuon, D.; Gong, Y.; Bigio, E.H.; Shaw, P.; et al. Monoclonal antibodies that target pathological assemblies of A $\beta$. J. Neurochem. 2007, 100, 23-35. [CrossRef]

133. Wildburger, N.C.; Esparza, T.J.; Leduc, R.D.; Fellers, R.T.; Thomas, P.M.; Cairns, N.J.; Kelleher, N.L.; Bateman, R.J.; Brody, D.L. Diversity of Amyloid-beta Proteoforms in the Alzheimer's Disease Brain. Sci. Rep. 2017, 7, 9520. [CrossRef]

134. Condello, C.; Stöehr, J. A $\beta$ propagation and strains: Implications for the phenotypic diversity in Alzheimer's disease. Neurobiol. Dis. 2018, 109, 191-200. [CrossRef]

135. Cline, E.N.; Das, A.; Bicca, M.A.; Mohammad, S.N.; Schachner, L.F.; Kamel, J.M.; DiNunno, N.; Weng, A.; Paschall, J.D.; Bu, R. Lo; et al. A novel crosslinking protocol stabilizes amyloid $\beta$ oligomers capable of inducing Alzheimer's-associated pathologies. J. Neurochem. 2019, 148, 822-836. [CrossRef]

136. Gibbs, E.; Silverman, J.M.; Zhao, B.; Peng, X.; Wang, J.; Wellington, C.L.; Mackenzie, I.R.; Plotkin, S.S.; Kaplan, J.M.; Cashman, N.R. A Rationally Designed Humanized Antibody Selective for Amyloid Beta Oligomers in Alzheimer's Disease. Sci. Rep. 2019, 9, 9870. [CrossRef]

137. Sevigny, J.; Chiao, P.; Bussière, T.; Weinreb, P.H.; Williams, L.; Maier, M.; Dunstan, R.; Salloway, S.; Chen, T.; Ling, Y.; et al. The antibody aducanumab reduces $A \beta$ plaques in Alzheimer's disease. Nature 2016, 537, 50-56. [CrossRef]

138. Rogers, M.B. Exposure, Exposure, Exposure? At CTAD, Aducanumab Scientists Make a Case. Available online: https://www.alzforum.org/news/conference-coverage/exposure-exposure-exposure-ctadaducanumab-scientists-make-case\#comment-34176 (accessed on 29 September 2020).

139. Biogen. FDA Accepts Biogen's Aducanumab Biologics License Application for Alzheimer's Disease with Priority Review|Biogen. Available online: https://investors.biogen.com/news-releases/news-release-details/ fda-accepts-biogens-aducanumab-biologics-license-application (accessed on 29 September 2020).

Publisher's Note: MDPI stays neutral with regard to jurisdictional claims in published maps and institutional affiliations.

(C) 2020 by the authors. Licensee MDPI, Basel, Switzerland. This article is an open access article distributed under the terms and conditions of the Creative Commons Attribution (CC BY) license (http://creativecommons.org/licenses/by/4.0/). 